\title{
INFLUENCE OF PRODUCT INNOVATION AND SERVICE QUALITY ON PURCHASE DECISION IN JAMBI ARINY BATIK IN KELURAHAN PASIR PANJANG JAMBI KOTA SEBERANG
}

\author{
Agesha Marsyaf \\ Management study program, Faculty of Economics and Business, Muhammadiyah Jambi University \\ Corresponding author: agesha.marsyaf.am@gmail.com
}

\begin{abstract}
Batik is a national cultural asset that has been inherited from generation to generation to every generation until now. Batik represents one of the creative handicraft industries in Indonesia which is rooted in culture and is able to provide employment and entrepreneurship in Indonesia, one of which is the Jambi area. Like other products, in order to be able to compete in the Jambi batik product market, it is necessary to understand the market's needs. Therefore, the authors took the title "The Effect of Product Innovation and Service Quality on Purchasing Decisions in Batik Jambi Ariny in the Kelurahan Pasir Panjang Jambi, Kota Seberang".The method used is a survey method. The data used are primary data obtained from direct interviews using a questionnaire. Data obtained through multiple linear regression analysis using the SPSS application.The results showed that product innovation and service quality had a positive and significant impact on purchasing decisions. On Batik Jambi Ariniy. Meanwhile, innovation and service quality simultaneously contributed $42.3 \%$ to the purchasing decision at Batik Jambi Ariny.
\end{abstract}

Keywords: Product Innovation, Service Quality, Purchasing Decisions

\section{Introduction}

At the beginning of the New Order government, the mining and oil and gas sectors were the largest foreign exchange earners from the export side. The development of export-oriented industries was a priority for industrial development at that time. Industrial development still focuses on developing import substitution industries that are oriented towards the domestic market. The textile industry in Indonesia has a big role in national development. This can be seen both from the increase in production, exports, and even the high absorption of labor that can be absorbed by the textile industry sector. The rapid development of the textile industry is influenced by the provision of several production factors that are needed for the continuity of a production process (Mas Aini Fitri, 2011).

Textiles are materials from fibers that are processed into fabrics or yarn as materials for making clothing and other products. The textile industry is one of the industries that is growing quite rapidly in Indonesia and is an industry that is relied on to meet the needs of National clothing. One type of textile industry that is engaged in Indonesia is batik.

Batik is a national cultural asset that has been inherited from generation to generation to every generation until now. The uniqueness of Indonesian batik cannot be compared to batik in other countries because Indonesian batik is different not only in the manufacturing process but also with different motives because it is related to a symbol of life which is full of the philosophical values of this nation (Singgih and Prasetyo, 2016).

Batik represents one of the creative handicraft industries in Indonesia which is rooted in culture and is able to provide employment and entrepreneurship in Indonesia, one of which is the Jambi area. Based on UNESCO's decision, batik has been legalized as a Cultural Heritage belonging to Indonesia. This has resulted in higher public appreciation for batik, not only local communities but also international communities. Batik is a product that is worn not only at formal but also informal events, so that the batik industry then becomes an industry that is considered to be able to contribute to improving the real economic sector, especially in the current industrialization era (Adhanita, S, 2013). by many choices in influencing consumers. Apart from going through promotions, the quality of products and services must also be improved. Not only that, business competition also means that companies must be able to make innovative products. the batik industry which is classified as innovation makes a business continue to grow. Innovation in variety, style, and color is one of the most important innovations applied to art products and contains elements of local culture (Dhewanto et al, 2015).

Jambi's batik and weaving (songket) are the handicraft products of Jambi Malay culture that have long been known to the international level. Batik has become an economic product that has sales value, especially after the craftsmen diversify new products of various shapes, types and varieties through creativity and innovation, in order to attract consumer tastes and penetrate a wide market (Karmela, 2015). Like other products, in order to be able to compete in the Jambi batik product market, it is necessary to understand the market's needs. Business players in the Jambi batik industry must be able to create competitive advantages in the form of uniqueness and product characteristics that competitors cannot imitate and can provide superior 
value to customers. This means that Jambi batik products must provide something of value to consumers. As a product innovation, the quality of service to consumers is also something that must be considered. A company must also look at the quality of service that employees have. Service quality is the level of excellence expected and control over that level of excellence is to meet market demand.

Batik Ariny is the original creation of batik craftsmen in Jambi City, apart from providing a choice of various batik patterns that already exist in Jambi City, Batik Ariny Jambi City dares to take innovations in the products offered, one of the innovations provided by Batik Ariny Jambi City is to provide choices. color, the choice of colors offered by Batik Ariny Jambi City by giving a touch of natural colors, so the colors given make people who wear batik more attractive and do not seem to be bad when worn. In addition to the innovations provided by Ariny batik above, Ariny batik also has other advantages in the products offered, especially the advantages of similar Jambi batik products, where these advantages can be seen from the batik making process itself. where the manufacture is purely done using a manual system or not using a machine at all, this process can make the product have a wide variety of attractive patterns and motifs that are not marketable, and besides that Ariny batik excellence is also supported by Jambi City government agencies, where Ariny batik is under the guidance of the Jambi City Industry and Trade Service. Competition in the business world is something that cannot be avoided, with the existence of competition, companies are faced with various opportunities and threats both from outside and from within the country. For this reason, every company is required to always understand and understand what is happening in the market and what consumers want. as well as various changes in the business environment so that they are able to compete with other companies (Anggraini, 2017).

Batik Jambi Ariny is one of the UMKM (Micro, Small and Medium Enterprises) owned by Mr. Taufik, S.Ag in the field of batik on Jalan KH.M.Shaleh Rt.03, Pasir Panjang Village, Danau Teluk District, Jambi City Seberang. Batik Jambi Ariny had experienced a decline in turnover due to decreased purchases. To maintain these MSMEs, many efforts have been made, one of which is by making innovations which are expected to provide attractiveness to the products being marketed. This increasingly varied market condition makes consumers selective in making purchases and increasingly critical in their buying behavior. Therefore, to determine whether there is an effect of product innovation and service quality, especially at centers that raise regional characteristics, one of which is Jambi batik, the researcher takes the title "The Influence of Product Innovation and Service Quality on Purchasing Decisions in Jambi Ariny Batik in Pasir Panjang Jambi, Seberang City.

\section{Research Method}

This research was carried out with a survey research method. The data collected in this study include primary data. Primary data were obtained from direct interviews using a questionnaire to the object of research, namely batik Ariny customers. The sample of this study used the Slovin formula with a total sample of 80 respondents. Statistical data processing in this study used a computer program application or Statistical Product and Service Solution (SPSS) for 22. Before processing statistical data with SPSS for 22. To get answers to the problem formulation in this study, multiple linear regression analysis tools were used., with multiple linear regression equation is as follows:

$$
\mathrm{Y}=\alpha+++\mathrm{e} \beta_{1} X_{1} \beta_{2} X_{2}
$$

\section{Result and Discussion \\ Characteristics of Respondents Based on Gender}

Table 1. Consumer Characteristics Based on Gender

\begin{tabular}{lcc}
\hline \multicolumn{1}{c}{ Gender } & Respondents & Percentage (\%) \\
\hline Male & 57 & 71.24 \\
\hline Women & 23 & 28.75 \\
\hline amount & 80 & 100.00 \\
\hline \multicolumn{2}{l}{ Source: Field Research Results (Primary Data) }
\end{tabular}

Based on the table above, it is known that based on the characteristics of gender there are $71.24 \%$ male consumers and $28.75 \%$ female consumers, it can be said that Jambi Ariny batik consumers are more preferred by men, this can occur because of the design and the color of many men who love Ariny batik. Age is a consideration that can be seen by a person to make a decision and becomes a measure of emotional maturity. 


\section{Consumer Characteristics Based on Age}

Table 2. Consumer Characteristics Based on Age

\begin{tabular}{ccc}
\hline \multicolumn{1}{c}{ Age } & Respondents & Percentage $(\boldsymbol{\%})$ \\
\hline 15-25 Years & 12 & 15.00 \\
\hline 26-35 Years & 32 & 40.00 \\
\hline $36-45$ years & 15 & 18.75 \\
\hline 46-55 Years & 21 & 26.25 \\
\hline amount & 80 & 100.00 \\
\hline Source Field Reserch Results (Primary
\end{tabular}

Source: Field Research Results (Primary Data)

Based on the table above, it is known that based on age characteristics there are $12 \%$ of consumers aged $15-25$ years, $32 \%$ aged $26-35$ years, $15 \%$ aged $36-45$ years, and $21 \%$ aged $46-55$ years. It can be seen that the largest percentage is $32 \%$ of consumers aged $26-35$ years.

\section{Consumer Characteristics Based on Education}

Table 3. Consumer Characteristics Based on Education

\begin{tabular}{lrr}
\hline \multicolumn{1}{c}{ Last education } & Respondents & Percentage (\%) \\
\hline Senior high school / equivalent & 21 & $26.25 \%$ \\
\hline Academy / (D, 1, D2, D3) & 5 & $6.25 \%$ \\
\hline Bachelor (S1 / equivalent) & 33 & $41.25 \%$ \\
\hline S2 & 15 & $18.75 \%$ \\
\hline S3 & 6 & $7.50 \%$ \\
\hline amount & 80 & $100.00 \%$ \\
\hline Source: Field Research Results (Primary Data) & &
\end{tabular}

Based on the table above, it can be seen that from the level of education, it is found that buyers who have a Bachelor or Bachelor degree, dominate the purchase of Jambi Ariny batik.

\section{Consumer Characteristics Based on Occupation}

Table 4. Consumer Characteristics Based on Occupation

\begin{tabular}{lrr}
\hline \multicolumn{1}{c}{ Type of work } & Respondents & Percentage (\%) \\
\hline Housewife & 3 & $3.75 \%$ \\
\hline Student / Student & 7 & $8.75 \%$ \\
\hline State Civil Apparatus (ASN) & 46 & $57.50 \%$ \\
\hline Entrepreneur & 16 & $20.00 \%$ \\
\hline Others & 8 & $10.00 \%$ \\
\hline amount & 80 & $100.00 \%$ \\
\hline Source: Field Research Results (Primary Data) &
\end{tabular}

Based on the table above, it is known that based on the type of work there are $3.75 \%$ housewives, $8.75 \%$ students / students, $57.5 \%$ employees (private / public), $20 \%$ entrepreneurs, and $10 \%$ others. It can be seen that the largest percentage is $57.5 \%$ namely State Civil Apparatus)

\section{Characteristics of Consumers Based on Income}

Table 5. Characteristics of Consumers Based on Income

\begin{tabular}{lll}
\hline \multicolumn{1}{c}{ Income } & Respondents & Percentage $(\%)$ \\
\hline$<1,000,000$ & 3 & $3.75 \%$ \\
\hline $1,000,000-2,000,000$ & 14 & $17.5 \%$ \\
\hline $2,000,000-3,000,000$ & 57 & $71.25 \%$ \\
\hline Above $3,000,000$ & 6 & $7.5 \%$ \\
\hline amount & 80 & $100 \%$ \\
\hline Source: Field Research Results (Primary Data)
\end{tabular}

Based on the table above, it is known that based on the income characteristics there are $3.75 \%$ of consumers who have an income below Rp. 1,000,000, 17.5\% have an income of Rp. 1,000,000 - Rp. 2,000,000, 71.25\% have an income of Rp. 2,000,000 - Rp. 3,000,000, and 7.5\% have an income above Rp. $3,000,000$. It can be seen that the largest percentage is consumers who have an income of Rp. 1,000,000 - Rp. $2,000,000$ per month. 


\section{Hypothesis testing \\ Partial Test (T Test)}

$\mathrm{T}$ test is conducted to determine the effect of each independent variable on the dependent variable. Ha tested is a parameter which is not equal to zero and Ho is a parameter which is equal to zero. The way to do this is by comparing the statistical value $t$ with the critical point according to the table, if tcount $>$ ttable then Ha is accepted, to see the calculation results found in this study, we can see in the table below

Table 6. Partial Test (T Test)

\begin{tabular}{lrrrrr}
\hline & \multicolumn{7}{c}{$\begin{array}{c}\text { Standardized } \\
\text { Mnstandardized Coefficients }\end{array}$} & \multicolumn{2}{c}{ Coefficients } & & \\
\cline { 2 - 4 } Model & \multicolumn{1}{c}{ B } & Std. Error & \multicolumn{1}{c}{ Beta } & \multicolumn{1}{c}{ Sig. } \\
\hline (Constant) & 21,972 & 2,0207 & & 10,948 &, 000 \\
Inovasi Produk &, 168 &, 039 &, 396 & 4,257 &, 000 \\
Kualitas Pelayanan &, 209 &, 050 &, 392 & 4,218 &, 000 \\
\hline
\end{tabular}

a. Dependent Variable

The following will explain the partial testing of each variable: (1). Product Innovation Variable (X1), Based on the results of the partial test ( $t$ test) between the Product Innovation variable (X1) on the Purchase Decision $(\mathrm{Y})$, it was found that the $\mathrm{t}$-count value was 4.257> $\mathrm{t}$ table 1.664 with a significance level of 0.000 . Thus, it means that the Product Innovation variable (X1) has a positive and significant effect on Purchasing Decisions (Y); (2) Service Quality Variable (X2), Based on the results of testing with SPSS 22 between the Service Quality (X2) variable on the Purchasing Decision (Y), the tcount value is 4.218> ttable 1.664 with a significance level of 0.000. This means that the Service Quality variable (X2) has a positive and significant effect on Purchasing Decisions (Y).

From the Coefficients table above, a multiple linear regression equation can be made as follows:

$$
\mathrm{Y}=21,972+0.168+0.209 \mathrm{X} \_1 \mathrm{X} \_2
$$

The following is an explanation of the multiple linear regression equation above: (1) A constant of 21,972 means that if Product Innovation () and Service Quality () are 0, then the Purchase Decision is worth 21,972X_1 X_2; (2) The product innovation variable regression coefficient () is 0.168 , meaning that if the innovation of Jambi Ariny's batik products increases by $1 \%$, it will affect the purchase decision (Y), or the purchase decision will increase by $16.8 \%$. The coefficient is positive, meaning that there is a positive relationship between Product Innovation and Purchasing Decisions, the higher the value of Product Innovation, the higher the value of the Purchasing Decision.X_1

The regression coefficient of the Service Quality variable () is 0.209 , meaning that if the service quality of Jambi Ariny's batik increases by $1 \%$, the purchase decision (Y) will increase by $20.9 \%$. The coefficient is positive, meaning that there is a positive relationship between Service Quality and Purchasing Decisions, the higher the Service Quality value, the more the Purchase Decision value will increase.X_2

\section{Simultaneous Test (Test F)}

The $f$ test is intended to determine the effect of the independent variables (Product Innovation and Service Quality) simultaneously or together on the dependent variable (Purchase Decision). This test is done by comparing the fcount with the table or it can also use the observation of the significant value of $\mathrm{F}$ at the $\alpha$ level used, which is $5 \%$. The results of the f Test calculation can be seen in the following table

Table 7. Simultaneous Test (Test F)

\begin{tabular}{lrrrrr}
\hline Model & Sum of Squares & df & Mean Square & F & Sig. \\
\hline $1 \quad$ Regression & 59,229 & 2 & 29,614 & 28,249 &, $000^{\text {b }}$ \\
Residual & 80,721 & 77 & 1,048 & & \\
Total & 139,950 & 79 & & & \\
\hline
\end{tabular}

a. Dependent Variable

b. Predictors: (Constant)

At the level of confidence 0.05 , it is obtained that the profitability of Fcount 28.249> Ftable 3.12 so that Ho is accepted, it means that product innovation and service quality together have a significant influence on the decision to buy batik Jambi Ariny. 
Determination Test $\mathrm{R}^{2}$

$\mathrm{R}^{2}$ aims to measure how far the model's ability to explain the variation in the dependent variable. In this study, the calculation is to measure how far the ability of the independent variable to explain the dependent variable $\mathrm{R}^{2}$

Table 8. Determination Test $\left(\mathrm{R}^{2}\right)$

\begin{tabular}{llrrr}
\hline Model & R & R Square & Adjusted R Square & \multicolumn{1}{c}{ Std. Error of the Estimate } \\
\hline 1 &, $651^{\text {a }}$ &, 423 &, 408 & 1,024 \\
\hline a. Predictors: (Constant) & & &
\end{tabular}

From the analysis of data processing between variables (Product Innovation and Service Quality) on Purchasing Decisions in purchasing batik, it shows that the value of $\mathrm{R}=0.651$. This means that the variable correlation (Product Innovation and Service Quality) on the Purchase Decision in purchasing batik has a close and positive relationship because the correlation coefficient value is close to +1 . The considered coefficient of determination (Adjusted R Square) is 0.408 or $40.8 \%$, where the relationship that can be explained by the two independent variables, namely Product Innovation and Service Quality on Purchasing Decisions is $40.8 \%$. While the remaining $59.2 \%$ is influenced or explained by other variables outside the independent variables used in this study

\section{Discussion}

The Influence of Product Innovation and Service Quality Partially on Purchasing Decisions in Jambi Ariny Batik in Pasir Panjang Village, Jambi City, Seberang.

\section{Product Innovation}

Based on the results of the previous $t$ test, the $t$ value for the Product Innovation variable was 4.257 and the $t$ table value was 1.664 with a significance level of 0.000 because tcount> ttable $(4.257>1.664)$ and the significance value was less than $0.05(0.000<0.05)$. Ha is accepted, meaning that there is a partially significant influence between Product Innovation variables on Purchasing Decisions on Jambi Ariny batik in Pasir Panjang Jambi Village, Seberang City. Then the regression coefficient value of the Product Innovation variable () is positive at 0.168 , meaning that if the other independent variable (Service Quality) is fixed and the Purchase Decision has increased by $1 \%$, the Purchase Decision (Y) will increase by $16.8 \%$. The coefficient is positive, meaning that there is a positive relationship between Product Innovation and Purchasing Decisions. From the description above, it can be concluded that there is a positive and partially significant influence between Product Innovation variables on Purchasing Decisions on Jambi Ariny batik in Pasir Panjang Jambi Village, Seberang City. This is in accordance with the opinion of Zhorif (2018), namely product innovation can increase purchasing decisions where if the value of an innovation increases, the purchase decision will increase.X_1

2. Service quality

Based on the results of the previous t-test, the t-test value for the Service Quality variable was 4.218 and the $t$-table value was 1.664 with a significance level of 0.000 . Because tcount $>$ ttable $(4,218>1,664)$ and a significance value less than $0.05(0,000<0.05)$ then $\mathrm{Ha}$ is accepted, meaning that there is a partially significant influence between the Service Quality variable on the Purchase Decision on Batik Jambi Ariny in Pasir Panjang Village. Jambi City Seberang. Then the regression coefficient value of the Service Quality variable () is 0.209 , which means that if the other independent variable (Product Innovation) is fixed and the Service Quality has increased by $1 \%$, then Purchasing Decision (Y) will increase by $20.9 \%$. The coefficient is positive, meaning that there is a positive relationship between Service Quality and Purchasing Decisions, the higher the Service Quality value, the more the Purchasing Decision value will be increased. From the description above, it can be concluded that there is a positive and partially significant influence between Service Quality variables on Purchasing Decisions on the purchase of Jambi Ariny batik in Pasir Panjang Jambi Village, Seberang City. This supports and is in accordance with the opinion of Kodu (2013) where the quality of service can improve purchasing decisions, in this case the purchase decision for the Toyota Avanza car. It can be concluded that there is a positive and partially significant influence between Service Quality variables on Purchasing Decisions on the purchase of Jambi Ariny batik in Pasir Panjang Jambi Village, Seberang City. This supports and is in accordance with the opinion of Kodu (2013) where the quality of service can improve purchasing decisions, in this case the purchase decision for the Toyota Avanza car. It can be concluded that there is a positive and partially significant influence between Service Quality variables on Purchasing Decisions on the purchase of Jambi Ariny batik in Pasir Panjang Jambi Village, Seberang City. This supports and is in accordance with the opinion of Kodu (2013) where the quality of service can improve purchasing decisions, in this case the purchase decision for the Toyota Avanza car.X_2 


\section{The Effect of Product Innovation and Service Quality Simultaneously on Service Quality in Jambi} Ariny Batik in Pasir Panjang Jambi Village, Sebrang City

Based on the results of the F test (simultaneous) previously, it is known that the Fcount value is 28.249 and the F-table value is 3.12 with a significance level of 0.000. Because Fcount> Ftable (28.249> 3.12) and a significance value $<0.05(0.000<0.05)$ then $\mathrm{Ha}$ is accepted, meaning that the Product Innovation and Service Quality variables simultaneously or together have a significant effect on Purchasing Decisions on batik purchases. Jambi Ariny in Pasir Panjang Village, Jambi City, Seberang. The influence of Product Innovation and Service Quality variables together on Purchasing Decisions can also be seen in the multiple correlation coefficient (R) of 0.651 or $65.1 \%$, which means that the relationship between Product Innovation and Service Quality variables together on Purchasing Decisions is strong. and positive because it is more than $50 \%$. While the coefficient of determination (R Square or R2) is 0.423 or $42.3 \%$, which means the contribution of the two independent variables, namely Product Innovation and Service Quality, to the dependent variable, namely the Purchase Decision collectively (simultaneously) of $42.3 \%$. While the remaining $57.7 \%$ is influenced or explained by other variables outside the independent variables used in this study. This is in accordance with the opinion of Zhorif (2018), where product innovation and service quality can jointly improve batik purchasing decisions While the remaining $57.7 \%$ is influenced or explained by other variables outside the independent variables used in this study. This is in accordance with the opinion of Zhorif (2018), where product innovation and service quality together can improve batik purchasing decisions While the remaining $57.7 \%$ is influenced or explained by other variables outside the independent variables used in this study. This is in accordance with the opinion of Zhorif (2018), where product innovation and service quality together can improve batik purchasing decisions

\section{Conclusion}

Based on the results of the analysis and discussion previously described, several conclusions can be drawn from the overall research results, namely as follows:

1. Based on the results of partial testing (t test) between Product Innovation () and Service Quality () variables on Purchasing Decisions (Y), it is found that the Product Innovation variable () has a positive and significant effect on Purchasing Decisions (Y).X_1 X_2 X_1

2. Based on the results of the F test, it can be concluded that the variable Product Innovation () and Service Quality () simultaneously have a significant effect on the Purchasing Decision variable (Y).X_1 X_2

3. Based on the Determination Test (Test R2) it was concluded that the Product innovation variable (X1) and Service Quality (X2) had a joint contribution of $42.3 \%$ to the Purchasing decision variable (Y)

\section{References}

Adhinata, S. 2013. Pengembangan Batik Jambi Motif Sungai Penuh sebagai Bentuk Kontribusi pada Pembangunan.Biro Penerbit Planologi Universitas Diponegoro. Volume 9 (4).

Alamsyah,2012. Kerajinan Batik dan Pewarnaan Alami. Jurnal Ilmiah Kajian Antropologi. Fakultas Ilmu Budaya. Universitas Diponegoro Semarang. 2599-1078.

Anggraini, C.P. 2017. Strategi Pemasaran Meningkatkan Daya Saing Perkembangan Batik. Tesis. Magister Manajemen. Universitas Widya Wiwaha Yogyakarta.

Azrori, M. 2018. Pengaruh Inovasi Produk dan Kualitas Pelayanan Terhadap keputusan Pembelian Pada batik Jambi Zhorif di Kecamatan danau Teluk Jambi Kota Seberang. Skripsi. Fakultas Bahasa Dan SeniUniversitas Negeri Padang.

Cristiani, D.M.2015. Pengaruh Kualitas Layanan, Kualitas Produk, dan Penetapan Harga, Terhadap keputusan Pembelian Pada CV. Esa Genangku (Esacom) Manado. Universitas Sam Ratulangi Manado.

Darwito. (2008). Analisis Pengaruh Gaya Kepemimpinan Terhadap Kepuasan Kerja dan Komitmen Organisasi Untuk Meningkatkan Kinerja Karyawan. Tesis. Program Studi Magister Manajemen Universitas. Diponegoro Semarang.

Dhewanto, Wawa dkk. 2015. Manajemen Inovasi Untuk Usaha Kecil dan Mikro, andng, Cv. Alfabeta.

Hadi dan Saputra. 2017. Pengaruh Inovasi Produksi dan Kualitas Pelayanan Terhadap Keputusan pembelian Pada CV. Suber Makmur Pakis-Malang.Jurnal Aplikasi Bisnis. Politeknik Negeri Malang.

Hair, Black, Babin, \&Anderson. (2010). Multivariate Data Analysis (7th edition). New Jersey : Pearson Education International.

Haryanto, A.T, Romdonah, R, dan fathoni, A. 2015. Pengaruh Inovasi Produk, Harga Dan Brand Image Terhadap Keputusan Pembelian Sepeda Motor Honda Beat (Studi Kasus Pada Konsumen Dealer Honda Pratama Kurnia Kasih)

Hubeis. 2012. Komunikasi Profesional.Bogor : IPB Press

Irawan, R, 2016. Pengaruh Inovasi Produk Dan Citra Merek Terhadap Keputusan Pembelian Makanan Ringan Yagi Yagi Di Easy Café Bandung. Program Studi Manajemen Fakultas Ekonomi Dan Bisnis Universita Komputer Indonesia

Karmela, S.H. 2015 Batik Dan Tenun : Cerminan Budaya Melayu Bagian Dari Ekonomi Dan Industri Kreatif Di Kota Jambi. Jurnal Ilmiah Universitas Batanghari Jambi Vol.15 No.4 
Kodu, S. 2013. Harga, Kualitas Produk Dan Kualitas Pelayanan Pengaruhnya Terhadap Keputusan Pembelian Mobil Toyota Avanza. Jurnal EMBA.Vol.1 No.3.Hal. 1251-1259.

Kumar. 2012. Marketing Reaserch 9 Edition. Jakarta. Tiga Serangkai

Kotler, Philip. 2011. Manajemen Pemasaran. Edisi tiga belas Bahasa.Indonesia.Jilid 1 dan 2.Jakarta , Erlangga.

Kountur, Ronny. (2012). Metode Penelitian untuk Penulisan Skripsi Dan Tesis. Jakarta: PPM.

Lan, Kavin. 2011. Marketing Management. Jakarta, Erlangga

Lesmana,M,T. Dan Nasution,A,E. 2018. Pengaruh Harga Dan Kualitas Pelayanan Terhadap Keputusan Pembelian Konsumen (Studi Kasus Pada Alfamart Di Kota Medan).Prosiding Seminar Nasional Vokasi Indonesia. Volume 1. 2654-6493.

Lestari, RD. 2017. Pengaruh Harga dan Kualitas Pelayanan Terhadap Keputusan pemeblian di Gulai Kepala Ikan Bang Jo. Skripsi. Universitas Islam negeri Sunan kalijaga. Yogyakarta.

Lupiyoadi, Rambat. 2013. Manajemen Pemasaran Jasa Berbasis Kompetensi.(Edisi 3). Jakarta: Salemba Empat.

Mas Aini Fitri. 2011. Analisis Faktor-Faktor Yang Berpengaruh Terhadap Volume Investasi Pada Industri Tekstil Di Indonesia, Thesis, Universitas Airlangga.

Notoatmodjo, S. 2010. Metodologi Penelitian Kesehatan. Jakarta : Rineka Cipta.

Rachmi, A, dan Ardiantika, D.B.C. 2017. Pengaruh Inovasi Produk Dan Brand Image Terhadap Keputusan Pembelian Pada Olivia Cake And Bakery Mojokerto. Jurnal Aplikasi Bisnis.Administrasi Niaga, Politeknik Negeri Malang.

Rasyid, H.A. dan Indah, A.T. 2018. Pengaruh Inovasi Produk dan Harga Terhadap Keputusan Pembelian Sepeda Motor Yamaha di Kota Tangerang Selatan. Perspektif Vol. XVI No. 1

Saryono (2011). Metodologi penelitiankesehatan, penuntun praktis bagi pemula. Yogyakarta : MitraCendikia Press.

Schiffman, Leon G., dan Kanuk, Leslie Lazar. 2012. Perilaku Konsumen. Alih bahasa Zulkifli Kasip. Jakarta : PT. Indeks Group Gramedia.

Singarimbun, M \& Effendi, S. (2011). Metode Penelitian Survai. Jakarta: LP3S.

Singgih dan Prasetyo. 2016. Karakteristik Motif Batik Kendal Interpretasi dari Wilayah dan Letak Geografis. Jurnal Imajinasi Vol X No.1 Hal $51-60$.

Sugiyono. 2008. Metode Penelitian Kuantitatif Kualitatif dan R\&D. Bandung :

ALFABETA

Sunyoto. 2012. Manajemen Sumber Daya Manusia. Jakarta: PT Buku Seru. http://repository.upi.edu/17628/4/S_MBS_1001311_Bibliography

Suryani, T. (2010). Perilaku Konsumen; Implikasi Pada Strategi Pemasaran. Yogyakarta: Graha Ilmu.

Susanto, A. 2013. Pengaruh Promosi, Harga Dan Inovasi Produk Terhadap Keputusan Pembelian Pada Batik Tulis Karangmlati Demak. Skripsi. Fakultas Ekonomi Universitas Negeri Semarang.

Susanto, Y.W. 2017. Pengaruh Inovasi Produk, Kualitas Produk Dan Harga Terhadap Keputusan Pembelian Di Toko Roti Dan Kue Ferissa Bantul Yogyakarta. Jurusan Manajemen, Fakultas Ekonomi, Universitas

PGRI Yogyakarta.

Susiawan dan Muhid. 2015. Kepemimpinan Transformasional, Kepuasan Kerja dan Komitmen Organisai.Persona, Jurnal Psikologi Indonesia. Vol.4 No. 03. Hal 304-313

Suryati.2013. Studi Tentang Sejarah Dan Asal-Usul Bentuk Motif Batik Jambi. Fakultas Bahasa Dan SeniUniversitas Negeri Padang.

Tejdhakusuma, R.; Hartini S. dan Muryani. 2012. Anaalisis Faktor-faktor yang Mempengaruhi Perilaku Konsumen dalam Pembelian Air Minum Mineral di Kotamadya Surabaya. Jurnal.

Tjiptono, Fandy,2010 : Service Marketing.; Marknesis, Yogyakarta.

Yogi Suwarno. 2008. Inovasi di Sektor Publik.Perpustakaan Nasional : Katalog dalam Terbitan.

Yuafni.2012. Faktor-Faktor Yang Mempengaruhi Produksi Batik Pada Industri Batik Jambi Di Kota Jambi.Skripsi. Fakultas Teknik Universitas Negeri Padang. 